\title{
Assessment of Heavy Metal Concentration in Hand Dug Well Water from Selected Land Uses in Wukari Town, Wukari, Taraba State, Nigeria
}

\author{
Kehinde T. Oyatayo ${ }^{1}$, Godwin A. Songuㅁ, Greatest A. Amos ${ }^{1}$, Christopher Ndabula ${ }^{2}$ \\ ${ }^{1}$ Department of Geography, Kwararafa University, Wukari, Nigeria \\ ${ }^{2}$ Department of Geography and Regional Planning, Federal University, Dutsin-Ma, Nigeria \\ Email: kehindeoyatayo@gmail.com
}

Received 23 September 2015; accepted 6 November 2015; published 9 November 2015

Copyright (C) 2015 by authors and Scientific Research Publishing Inc.

This work is licensed under the Creative Commons Attribution International License (CC BY). http://creativecommons.org/licenses/by/4.0/

(c) (i) Open Access

\begin{abstract}
Hand dug well water remains the major source of domestic (drinking) water in the city of Wukari. This study was aimed at the assessment of heavy metal concentration in hand dug well water from four land uses of abattoir (A), waste dump site (B), residential (C) and commercial (D) in Wukari Town, Wukari, Taraba State. There are about 76 hand dug wells in the study area and for the purpose of this study. Yamane (1967) sample size technique was adopted. Based on this, $95 \%$ confidence level and an error limit of $5 \%$ were adopted. Thus, four (4) samples A, B, C and D of hand dug well water purposively drawn from the study area used sterilized bottles. The heavy metals tested for in the water samples include: zinc ( $\mathrm{Zn})$, copper ( $\mathrm{Cu})$, manganese (Mn), iron (Fe), potassium (K), phosphate, and chromium. The results of the analyses were compared with the NSDWQ*MPL and FEPA (2001) standards. The results shows that the concentration of magnesium and manganese in hand dug well water samples $A, B, C$ and $D$ had higher concentrations than the maximum permissible limits of NSDWQ*MPL and FEPA (2001) standards and the concentration of zinc, copper, iron, potassium, phosphate and chromium in hand dug well water sample $A, B, C$ and D was at different compliance level with NSDWQ*MPL and FEPA (2001) standards. ANOVA (F-ratio) statistics at $P_{-} 0.05$ for variation in heavy metal concentration in hand dug well water from land uses A, B, C and D were insignificant. For now, it can be concluded that hand dug well water in Wukari Town is fit for domestic use, but that efforts should be made to reduce the magnesium and manganese concentration by having control on the anthropogenic factors that lead to such high concentration levels or else, soon this source of water may become unfit for domestic use. It was recommended that aggressive public awareness and enlightenment on possible impacts of hand dug well water pollution from human activities should be embarked upon by relevant agencies.
\end{abstract}




\section{Keywords}

\section{Heavy Metals, Hand Dug Well Water, Water Pollution, Safety Standard}

\section{Introduction}

Water is precious and necessary for a sustainable economic development of an area as it is the next major support to life after air. In the urban areas where pipe-borne water, bore-hole water and hand-dug wells are available, it is an indication that water is a vital component of human existence. Groundwater is of major importance and is intensively exploited for private, domestic and industrial uses. $90 \%$ of the population depends largely on hand-dug wells. Rapid growth in urban populations and industrial activities and commercial and agricultural developments result in increase in the search and uses of potable water [1]-[3].

A major source of groundwater abstraction for use is by means of a hand dug well. A well is a hole or shaft sunk into the earth for the purpose of obtaining water and other fluid from an underground supply. Such a hole can be constructed in different ways upon which wells are commonly classified as hand dug wells, borehole, among others. Hand dug wells are of vital importance as source of domestic water supply for the majority of Nigerians. Hand dug well water remain the major source of domestic (drinking) water in the city of Wukari. The quality of this hand dug well water across Nigeria is rarely analyzed nor treated before use. Until recently, most artificial wells in the country do not have pump. Hand dug wells are usually between 1 and 20 meter deep depending on the geological characteristics of the area, and lined with stone, bricks, and recently cemented rings [4] [5].

The spilling, leaking, improper disposal, or intentional application of chemicals at the land surface can result in runoff that contaminates nearby streams and lakes, or infiltration that contaminates underlying aquifers. The type and severity of water contamination often is directly related to human activity, which can be quantified in terms of the intensity and type of land use in the source areas of water to streams and aquifers.

A relatively simple way to study the effects of land use on groundwater quality is to compare the predominant land uses within a given area to the concentrations of selected contaminants in water drawn from shallow aquifers within that area. Analysis of the relation between land use and the magnitude of contamination in a specific area primarily is based on the following two assumptions [6]:

First, it is assumed that contaminated groundwater at a well originated as uncontaminated recharge (precipitation) that passed through a contaminated area before reaching the well. The area from which a well derives its water (and associated contaminants) is known as the well's groundwater "contributing area." Land use and land cover largely determine the type and amount of contaminants entering streams, lakes, and underground pathways, including aquifers. Some contaminants occur and move naturally, whereas others are produced by human activities and their movement often is accelerated as a result of rainfall that accentuates runoff and infiltration. Second, it is assumed that the contaminants detected in groundwater were present within the well's contributing area and were transported by groundwater flow to the well. The source(s) of contaminants within a contributing area, such as buried septic systems and leaking underground fuel tanks, can be difficult to identify and locate. In many instances, these sources can be inferred from the type and intensity of land use within the contributing area. Factors that can affect the movement of contaminants from source areas to wells are:

- The chemical nature of the contaminant;

- The physical properties of the soil and aquifer material;

- The amount and timing of recharge; and

- The direction and velocity of groundwater movement.

Heavy metals are elements having some atomic weight between 63.54 and 200.59, and a specific gravity greater than 4. Although trace amount of some heavy metals are required by living organisms, any excess amount of these metals can be detrimental to life [3]. The solubility of these metals in soils and groundwater is largely controlled by pH [1] [4] [7]; amount of metal and cation exchange capacity, organic carbon content and the oxidation state of mineral components as well as the redox potential of the system. Pollution of groundwater is an impairment of water quality by chemicals, heat or bacteria to a degree that does not necessarily create public health hazards, but does adversely affect such water for domestic, farm, municipal or industrial use. Trace 
elements are generally present in small concentration in natural water system. Their occurrence in groundwater and surface water can be due to natural sources such as dissolution of naturally occurring minerals containing trace elements in the soil zone or the aquifer material or to human activities such as mining, fuels, smelting of ores and improper disposal of industrial wastes [7]-[9] 2000 cited in: [2].

Heavy metals such as iron, manganese, cadmium, mercury, lead, arsenic, chromium, copper, Nickel, zinc cause a number of hazards to humans; and are indeed cofactors as activator biochemical reactions. Heavy metals are natural components of the earth's crust, as can neither be degraded nor destroyed. Through rivers and streams, the metals are transported as either dissolved species in water or as an integral part of suspended substances causing the most detrimental effects on aquatic life. Also, to a small extent, the metals enter the human bodies via food, drinking water and air. Though, some heavy metals (e.g. copper, selenium, zinc) are essential to maintain the metabolism of the human body, but their concentration above the desirable levels can be poisonous. Heavy metal poisoning could be from drinking-water contamination (e.g. lead pipes), high ambient air concentrations near emission sources, or intake via the food chain [2].

Heavy metals are dangerous because they tend to bioaccumulate. Bioaccumulation results when there is an increase in the concentration of a chemical in a biological organism over time, compared to the natural concentration of chemicals in the environment. Heavy metals may enter a water supply from industrial and household wastes, or acidic rain resulting in the breakdown of soils and releasing heavy metals into streams, lakes, rivers, and groundwater [8]. Investigation of heavy metals is very essential since slight changes in their concentration above the acceptable levels, whether due to natural or anthropogenic factors, can result in serious environmental and subsequent health problems. This study therefore seeks to investigate heavy metal concentration in hand dug wells in Wukari, with a view to ascertain whether this source of domestic water supply is safe for human consumption.

\section{Study Area}

\subsection{Location of the Study Area}

Taraba State is located in north eastern part of Nigeria as shown in Figure 1. Wukari is the headquarters of Wukari Local Government Area of Taraba State. It is located between latitude $7^{\circ} 51^{\prime} \mathrm{N}$ to $7^{\circ} 85^{\prime} \mathrm{N}$ and longitude $9^{\circ} 46^{\prime} \mathrm{E}$ to $9^{\circ} 78^{\prime} \mathrm{E}$ of the Greenwich meridian. Wukari Local Government area is situated in the southern part of Taraba State as shown in Figure 1. It is about two hundred kilometers away from Jalingo the state capital. The Local Government is bounded by Plateau State in the North, Benue State in the Southwest, Northeast by Karim Lamido, Bali, and Takum Local Government Area (LGA). It has an area of about 4308 km² (1663 sq mi). Figure 2 is the map of Wukari Local Government Area showing the study area.

\subsection{Physical Characteristics}

Wukari LGA covers an area of approximately $6500 \mathrm{sq}$. Km. The whole area is a gently undulating plain, with a mean altitude of $200 \mathrm{~m}$ above sea level. The drainage systems drain northward and serve as tributaries network to the River Benue while eastward discharge of rivulets and other smaller tributaries from Wukari town drains towards the Donga River, which is a major tributary of River Benue.

\subsection{Climate}

The study area is characterized with a tropical continental climate. According to Koppen's climate classification scheme, the climate of the study area corresponds to the Aw type of climate which is characterized by marked distinctive wet and dry season. The mean annual rainfall value ranges from $1000-1500 \mathrm{~mm}$. The unset of the raining season is usually around April while the offset period is October. This means the rainy season usually last for seven months and about five month of dryness from November to March. The mean maximum temperature is being experience around April at about $40^{\circ} \mathrm{C}$ while the mean minimum temperature occurs between the period of December and February at about $20^{\circ} \mathrm{C}$. Relative humidity also exhibit temporal variability. It is higher during the night hours in the rainy season than during the day hours in the dry season respectively. By location, the climate of the area is being influenced by the prevalence of two opposing air masses, the tropical maritime air mass (MT, south westerly's trade) and the tropical continental air mass (CT, north easterlies trade). The tropical continental air mass (CT) is a dry air that blows across the Sahara desert to the West African region. 


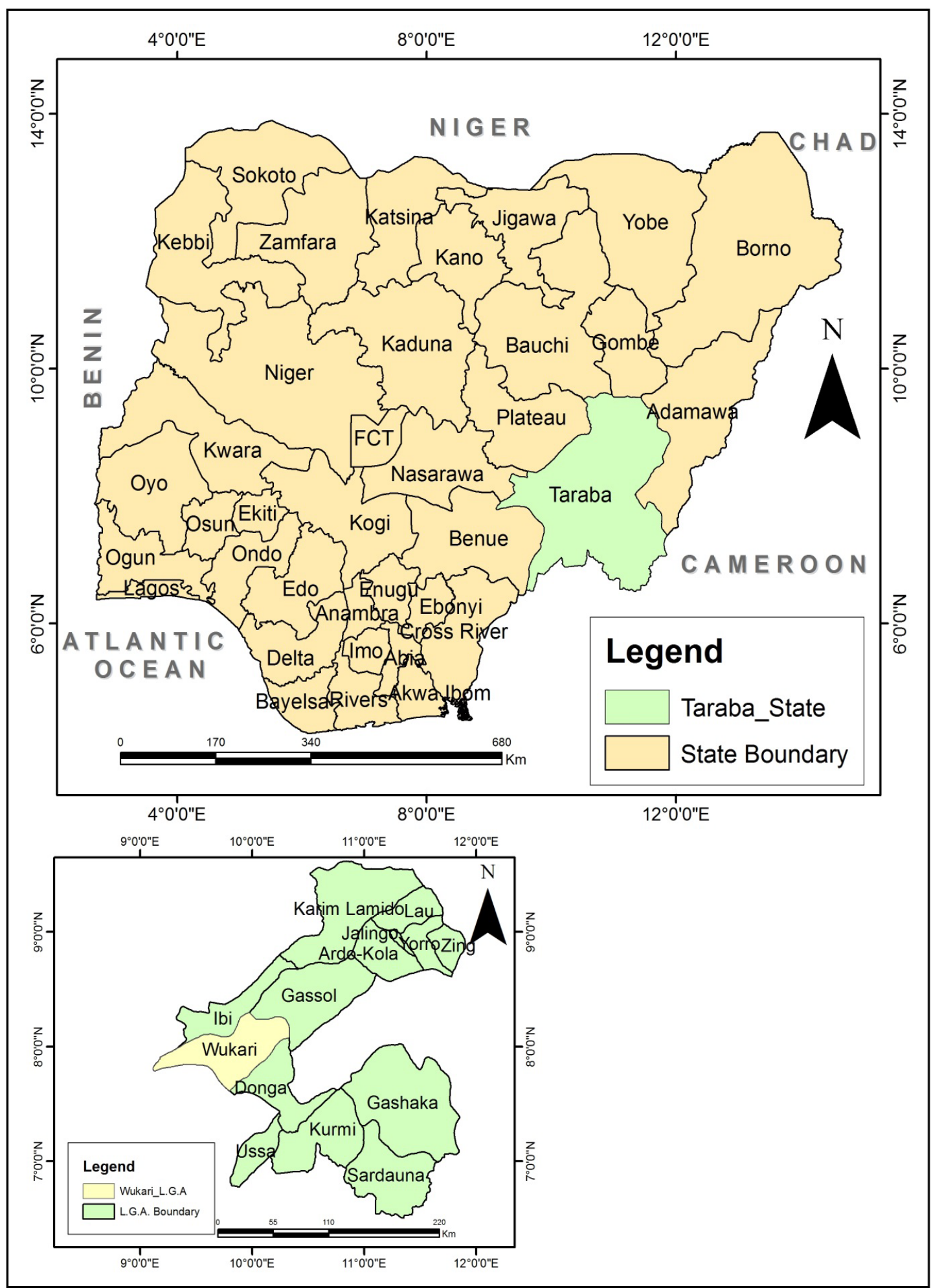

Figure 1. Map of Nigeria and Taraba State showing Wukari local Government Area. Source: Ministry of Land and Survey, Jalingo, Taraba State.

This air mass is commonly associated with cold, dry, and dusty condition. The tropical maritime air mass (MT) is characterized with warm, moist air from the 22 Atlantic Ocean south of the Nigeria. This air mass is responsible 


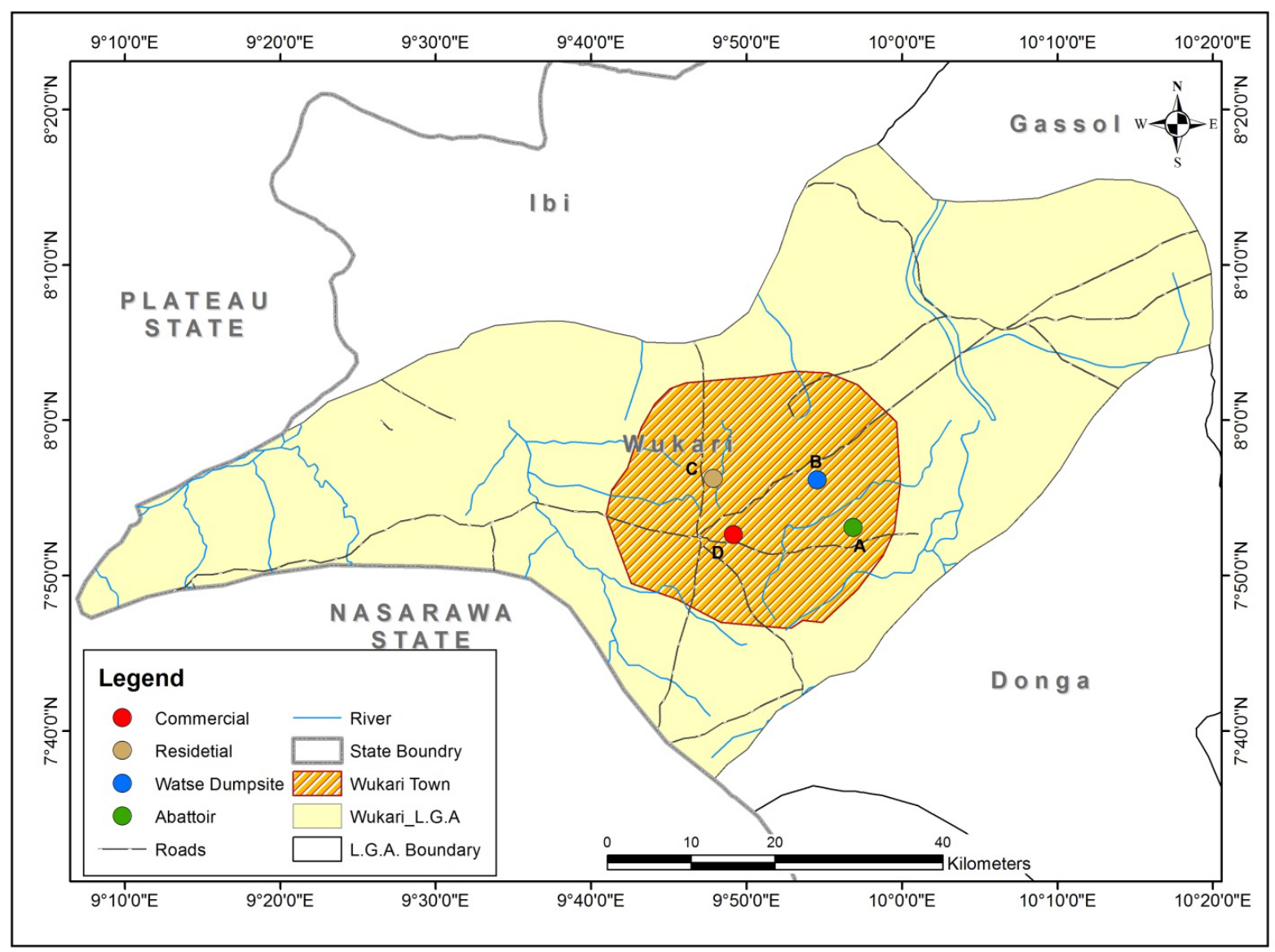

Figure 2. Map of the study area. Source: Ministry of Land and Survey, Jalingo, Taraba Sate.

for the rainy season and the former dry season. The confluence between these two air masses is known as the Inter tropical convergence zone (ITCZ).

\subsection{Geology, Soils and Vegetation}

Wukari is situated over cretaceous sandstone which is possibly Bima-sandstone. These rocks do not form adequate supplies of ground water for the township, so the public supply of water has to be supplemented through pumped water from the Donga River. The Wukari urban area is a relatively undissected, very gentle slope plain. The town is the beginning of the catchment areas for 6 major streams although no perennial streams intrude into the built-up area. The soils are deep, well drained and medium to coarse textured. The Wukari local government area falls within the southern guinea savannah zone. The vegetation manifest seasonal pattern, and it is mainly of tree savannah in which the dominant species is the dainiellia providing a limited amount of shade. The accompanying shrubs and grasses are of the hymenocardia and andropogon communities. There are also restricted areas of isoberlinia savannah woodland, which forms the forest reserves of the area. Other exotic species include eucalyptus, azadirachtaindica, and psidiumguajava, among others.

\section{Materials and Methods}

In order to achieve the aim and objectives of the study, the methodology that was employed in this study is subdivided into the following themes:

1) Reconnaissance survey.

2) Materials.

3) Methods and procedures of data collection.

4) Statistical analysis. 


\subsection{Reconnaissance Survey}

A reconnaissance survey of the study area was carried out to give a real time site assessment and also to acquire information about the township which may not readily be available in the topographic map. The research work was carried out in two main phases:

Phase I: reconnaissance survey.

Phase II: Field work where ground water samples were collected.

\subsection{Data Collection Procedure}

A total of four hand dug wells were sampled for analyses within Wukari Township. Bottles used in the collection of water samples were sterilized in an autoclave at a temperature of $120^{\circ} \mathrm{C}$ for three hours before duplicate samples of $100 \mathrm{ml}$ and 2 liters of each of the hand dug well water was collected for analyses, respectively. The heavy metals tested for in the water samples include: zinc $(\mathrm{Zn})$, copper $(\mathrm{Cu})$, manganese $(\mathrm{Mn})$, iron $(\mathrm{Fe})$, potassium $(\mathrm{K})$, phosphate, and chromium. These samples were labeled in order to avoid mix-up and were taken to the laboratory for analyses. The laboratory analyses of the water samples were carried out in Bauchi State Rural water supply and sanitation (RUWASSA), Bauchi, Bauchi State, Nigeria.

\subsection{Sampling Techniques}

There are about 76 hand dug wells in the study area and for the purpose of this study; a representation sample with known confidence and risk level was selected, based on the work of [10]. Based on this, 95\% confidence level and an error limit of 5\% were adopted. Thus, four (4) hand dug wells were sampled for the purpose of water quality analysis (heavy metal concentration) in the study area. Purposive sampling was used in picking the sampled hand dug wells in the study area based on the following land uses: A (closeness to Abattoir), B (closeness to waste dumping site), C (residential area) and D (closeness to commercial).

\subsection{Data Analysis}

To examine heavy metal concentration in hand dug well water from selected land uses in Wukari, [11] methodology for analyzing chemical parameters were adopted as follows: Copper, zinc, manganese, Chromium, Iron, potassium and Manganese were determined using Atomic Absorption Spectrophotometer; the concentration was read using UV spectrophotometer (Model: 01-0960-00) at $510 \mathrm{~nm}$. Finally, the laboratory results were compared with the Nigerian Standard for drinking water quality and FEPA minimum permissible limits.

\subsection{Statistical Analysis}

To examine whether there is variation in heavy metal concentration in hand dug well water from four land uses of A (abattoir), B (waste dump site), C (residential) and D (commercial) in Wukari town the following hypothesis was postulated:

H0: there is no significant variation in heavy metal concentration in hand dug well water from land uses of abattoir, waste dump site, residential and commercial in Wukari town.

The statistical test best suited to test the above hypothesis is the Analysis of Variance (ANOVA). This was done with the aid of the Statistical Package for Social Sciences (SPSS).

\section{Results and Discussion}

Magnesium: The amount of magnesium in the hand dug well water samples as obtained from the laboratory analysis is as follows: sample A, B, C, and D are 17.09, 20.76, 15.87 and 20.76 respectively as shown in Table 1. These values are higher than the NSDWQ*MPL and [12] effluent permission-able limit of $2.0 \mathrm{mg} / \mathrm{l}$ required for drinking water quality as shown in Table 2. High content of magnesium and calcium results to hardness of water. Magnesium has also been known to be essential for plants growth and development [2].

Copper: The amount of copper in the hand dug well water samples as obtained from the laboratory analysis is as follows: $0.09 \mathrm{mg} / \mathrm{l}, 0.07 \mathrm{mg} / \mathrm{l}, 0.12 \mathrm{mg} / \mathrm{l}$ and $0.02 \mathrm{mg} / \mathrm{l}$ for samples A, B, C and D respectively as shown in Table 1 . There is consistency in the values obtained from laboratory analysis and these values fall below the permissible limit of $1.0 \mathrm{mg} / \mathrm{l}$ set by NSDWQ*MPL and [12] as shown in Table 2. 
Table 1. Results of laboratory analysis of water samples A, B, C and D.

\begin{tabular}{|c|c|c|c|c|c|}
\hline Parameters & A & B & $\mathrm{C}$ & $\mathrm{D}$ & NSDWQ*MPL \\
\hline Calcium Ca (mg/1) & 60 & 68 & 92 & 66 & 75 \\
\hline Magnesium Mg (mg/1 & 17.09 & 20.76 & 15.87 & 20.76 & 2 \\
\hline Floride (mg/1) & 0.73 & 0.52 & 0.56 & 0.4 & 1 \\
\hline Copper Cu (mg/1) & 0.09 & 0.07 & 0.12 & 0.02 & 1 \\
\hline Iron Fe (mg/1) & 0.3 & 0.05 & 0.05 & 0 & 0.3 \\
\hline Potassium (mg/1) & 11 & 24 & 20 & 9.5 & 200 \\
\hline Sulphate (mg/1) & 7 & 7 & 30 & 4 & 100 \\
\hline Manganese Mn (mg/l) & 0.6 & 0.5 & 0.2 & 0.3 & 0.05 \\
\hline Nitrate $\mathrm{NO}_{3}(\mathrm{mg} / \mathrm{l})$ & 36.52 & 53.68 & 39.15 & 56.32 & 50 \\
\hline Nitrite NO (mg/l) & 0.043 & 0.013 & 0.013 & 0.073 & 0.2 \\
\hline Zinc (mg/l) & 0 & 0 & 0 & 0 & 5 \\
\hline Phosphate. (mg/l) & 0.85 & 0.07 & 0.3 & 0.37 & \#NAME? \\
\hline Chromium (mg/l) & 0.01 & 0.01 & 0.01 & 0 & 0.05 \\
\hline Sodium. Na (mg/l) & 41.25 & 48.13 & 50 & 32.41 & 200 \\
\hline Chloride $\mathrm{Cl}(\mathrm{mg} / \mathrm{l})$ & 104.97 & 122.46 & 139.96 & 82.47 & 250 \\
\hline $\mathrm{HCO}_{3}^{-}\left(\mathrm{mg}^{-1}\right)$ & 30 & 40 & 45 & 35 & 100 \\
\hline
\end{tabular}

Source: Field survey (2014).

Table 2. Comparison of the analyzed samples with the NSDWQ*MPL and FEPA acceptable limits.

\begin{tabular}{|c|c|c|c|c|}
\hline Parameters (mg/l) & Mean Values & NSDWQ*MPL/FEPA & Deviation & Remark \\
\hline Calcium Ca (mg/l) & 71.50 & 75 & -3.5 & Below limit \\
\hline Magnesium $\mathrm{Mg}^{2+}$ (mg/l) & 18.6150 & 2.0 & 16.615 & Acceptable limit \\
\hline Fluoride(mg/l) & 0.552500 & 1.0 & -0.4475 & Within limit \\
\hline Copper $\mathrm{Cu}^{2+}(\mathrm{mg} / \mathrm{l})$ & 0.057000 & 1.0 & -0.943 & Within limit \\
\hline Iron Fe (mg/l) & 0.1000 & 0.3 & -0.2 & Below limit \\
\hline Potassium (mg/l) & 16.125 & 200 & -183.875 & Below limit \\
\hline Sulphate (mg/l) & 12.00 & 100 & -88 & Below limit \\
\hline Manganese Mn (mg/l) & 0.400 & 0.05 & 0.35 & Acceptable limit \\
\hline Nitrate $\mathrm{NO}_{3}(\mathrm{mg} / \mathrm{l})$ & 46.4275 & 50 & -3.5725 & Below limit \\
\hline Nitrite $\mathrm{NO}_{2}$ & 0.035500 & 0.2 & -0.1645 & Below limit \\
\hline Zinc Zn (mg/l) & 0.00 & 5 & -5 & Below limit \\
\hline Phosphate (mg/l) & 0.397500 & - & 0.397500 & Acceptable limit \\
\hline Chromium (mg/l) & 0.0075 & 0.05 & -0.0425 & Below limit \\
\hline Sodium $\mathrm{Na}^{+}$(mg/l) & 44.197500 & 200 & -155.8025 & Below limit \\
\hline Chloride $\mathrm{Cl}^{-}$(mg/l) & 112.4650 & 250 & -137.535 & Below limit \\
\hline $\mathrm{HCO}_{3}^{-} \quad(\mathrm{mg} / \mathrm{l})$ & 37.50 & 100 & -62.5 & Below limit \\
\hline
\end{tabular}

Source: Field survey (2014). NSDWQ*MPL = Nigeria Standard for Water Quality and Minimum Permission Limit. FEPA = Federal Environment Protective Agency. 
Though still within permissible limits, some people who drink water containing copper in excess of the action level in short term may experience gastrointestinal distress while those with long-term exposure may experience anemia, liver or kidney damage. People with Wilson's disease should consult their personal doctor if the amount of copper in their water exceeds the action level. Also, long term exposure to water that contains copper can cause irritation of nose, mouth and eyes which can lead to headache, dizziness, vomiting and diarrhea among other health hazards [13].

Iron content: The amount of iron in sample A hand dug well water is $0.30 \mathrm{mg} / \mathrm{l}$, while samples B, C and D have values of $0.05 \mathrm{mg} / \mathrm{l}, 0.05 \mathrm{mg} / \mathrm{l}$ and $0.00 \mathrm{mg} / \mathrm{l}$ respectively as shown in Table 1 . The beneficial effects of iron include; chlorophyll synthesis, oxidation-reduction in respiration, constituent of certain enzymes and proteins. Excess concentration of iron has a negative effect as it can cause gastrointestinal irritation and enhance the growth of iron bacteria that affects the water taste. The high concentration values of iron has the potential of staining laundry, metal pipes for reticulation and scaling in pipes. It can also result in gene mutation leading to haemochromatosis whose symptoms include fatigue, weight loss, joint pains and ultimate heart disease, liver problems and diabetes [13]. The iron concentration of the sample ranges between $0.00-0.30$, when compared to NSDWQ*MPL and [12] limit, it is within the permissible limit of $0.3 \mathrm{mg} / \mathrm{l}$ as shown in Table 2.

Potassium: The concentration in the collected samples range between 9.5 - 24.0 as shown in Table 1 . The values are quite below the NSDWQ*MPL and [10] recommended limit of 200mg/l as shown in Table 2.

Manganese: The manganese concentration of hand dug well water samples was 0.6, 0.5, 0.2 and $0.3 \mathrm{mg} / \mathrm{l}$ for sample A, B, C and D respectively as shown in Table 1 . The values obtained far exceed SDWQ*MPL and [12] permissible limit of $0.05 \mathrm{mg} / \mathrm{l}$ as shown in Table 2.

Manganese impacts a bitter taste to water, stains cloths and metal parts and precipitate in foods when used for cooking and it also promotes the growth of algae in reservoirs [2].

Zinc: The amount of zinc in the hand dug well water samples as obtained from the laboratory analysis is as follows: $0.00 \mathrm{mg} / \mathrm{l}, 0.00 \mathrm{mg} / \mathrm{l}, 0.00 \mathrm{mg} / \mathrm{l}$ and $0.00 \mathrm{mg} / \mathrm{l}$ for samples A, B, C and D respectively as shown in Table 1 . The laboratory values obtained all fall within the permissible limits of $5 \mathrm{mg} / \mathrm{l}$ as stipulated by [12] and NSDWQ*MPL as shown in Table 2.

Chromium: The amount of chromium in the hand dug well water samples as obtained from the laboratory analysis is as follows: $0.01 \mathrm{mg} / \mathrm{l}, 0.01 \mathrm{mg} / \mathrm{l}, 0.01 \mathrm{mg} / \mathrm{l}$ and $0.00 \mathrm{mg} / \mathrm{l}$ for samples $\mathrm{A}, \mathrm{B}, \mathrm{C}$ and D respectively as shown in Table 1 . The laboratory values obtained all fall within the permissible limits of $0.05 \mathrm{mg} / \mathrm{l}$ as stipulated by [12] and NSDWQ*MPL as shown in Table 2. Since it is still below the permissible limit for drinking water quality, it shows that it has no implication on people who drink from the source. Water containing chromium in excess of the set limit may have an erythropoietin effect such as increased occurrence of goiter among humans and animals [1].

The findings from this study shows that the concentration of copper, iron, potassium, zinc and chromium in Wukari hand dug well water are all within the set permissible limit of [12] and NSDWQ*MPL as shown in Table 2. This confirms the findings of [2] which is supportive of the fact that heavy metals concentration in ground water in Obajana and environs are within the set limit of [12] and NSDWQ*MPL.

Also, the findings shows that the concentration of manganese and magnesium in Wukari hand dug well water exceeds the set permissible limit of [12] and NSDWQ*MPL, which corroborate the findings of [1] [3] [13]-[15] that asserts that ground water in some selected Nigerian settlements shows some elevated levels of toxic metals. This they observe is a source of worry considering the fact that typical settlementin Nigeria is devoid of basic infrastructure that makes life worth living.

\section{Statistical Analysis}

Statistical analyses using ANOVA single factor was conducted to test the null hypothesis that there is no significant variation in heavy metal concentration in hand dug well water from four different land uses of abattoir, waste dump site, residential and commercial in Wukari town. The summary of ANOVA single factor statistics is shown in Table 3. Using ANOVA single factor with a specified rejection level at $\alpha 0.05$, the result indicates that the calculated value (F calculated) is 0.21 , while the table value at $\mathrm{P}<0.05$ is 2.76 as shown in Table 4 . This result is insignificant which implies that there is no significant variation in heavy metal concentration in hand dug well water from land uses A (abattoir), B (waste dump site), C (residential) and D (commercial) in Wukari town. 
Table 3. Summary.

\begin{tabular}{ccccc}
\hline Groups & Count & Sum & Average & Variance \\
\hline A & 16 & 310.45 & 19.40 & 866.26 \\
B & 16 & 385.26 & 24.08 & 1213.22 \\
C & 16 & 433.23 & 27.08 & 1595.48 \\
D & 16 & 307.62 & 19.23 & 748.52 \\
\hline
\end{tabular}

Table 3 shows the summary of ANOVA single factor analysis.

Table 4. ANOVA.

\begin{tabular}{cccccc}
\hline Source of Variation & SS & $d f$ & MS & F & P-value \\
\hline Between Groups & 699.7881 & 3 & 233.26 & 0.21 & 0.89 \\
Within Groups & 66352.16 & 60 & 1105.87 & & \\
Total & 67051.95 & 63 & & \\
\hline
\end{tabular}

Using ANOVA single factor as shown in Table 4 with a specified rejection level at $\alpha 0.05$ the result is insignificant. The calculate $\mathrm{F}$ value is less than the table F value, thus, the Null hypothesis is to be accepted (There is no significant variation).

\section{Conclusion}

The result of the laboratory analysis shows that the concentration of iron, copper, chromium, zinc, potassium in hand dug well water in Wukari falls within the permissible limits of NSDWQ*MPL and [12]; while the concentration of manganese and magnesium far exceeds the permissible limits of NSDWQ*MPL and [12]. The results indicate that the drinking water quality is becoming deteriorated because most of the heavy metals tested for are found to be at minimum satisfactory level except for manganese and magnesium, which are found to be at unsatisfactory level because they are found to be at high levels in concentration. For now, it can be concluded that hand dug wells in Wukari Town are fit for domestic use, but that efforts should be made to reduce the magnesium and manganese concentration by having control on the anthropogenic factors (domestic waste water, agrochemicals, fumigation, local industries effluents) that lead to such high concentration levels or else, soon this source of water may become unfit for domestic use. The conclusion also is that there is no significant variation of heavy metal concentration in hand dug well water from land uses of abattoir, waste dump site, residential and commercial in Wukari town.

\section{References}

[1] Magaji, J.Y. (2009) The Impact of Waste Dump on Soil and Water Quality. A Case Study of Mpape Dumpsite, FCT, Abuja. An Unpublished Ph.D. Thesis Submitted to the Department of Geography and Environmental Management, University of Abuja, Abuja.

[2] Musa, O.K., Shuaibu, M.M. and Kudamnya, E.A. (2013) Heavy Metal Concentration in Groundwater around Obajana and Its Environs, Kogi State, North Central Nigeria. American Journal of Contemporary Research, 3, 170-177.

[3] Ogunlaja, A. and Ogunlaja, O.O. (2007) Physico-Chemical Analysis of Water Sources in Ubeji Community and Their Histological Impact on Organs of Albino Mice. Journal of Environmental Management, 11, 91-94.

[4] Huisman, L. (1986) Lecture Notes on Groundwater Recovery. Belgrade, Yugoslavia, Art B 8-3-8-4.

[5] Ajibade, L.T., Ogunkolu, A.B. and Ogundare, I.O. (2014) Physico-Chemical and Biological Characteristics of Hand Dug Well Water in Ilorin Metropolis, Nigeria. Nigeria Geographical Journal, 9, 146-162.

[6] Eckhardt, D.A. and Stackelberg, P.E (1995) Relation of Ground-Water Quality to Landuse on Long Island, New York. Ground Water, 33, 1019-1033. http://dx.doi.org/10.1111/j.1745-6584.1995.tb00047.x

[7] Kennish, M.J. (1992) Ecology of Estuaries Anthropogenic Effects. CRC Press, Inc., Boca Raton, 494 p.

[8] Ajibade, O.M., Omisanya, K.O. and Odunsi, G.O. (2011) Groundwater Portability and Flow Direction of Urban Aquifer, Ibadan Southwest Nigeria. Journal of the Nigerian Association of Hydrologist, 21, 38-55.

[9] Martinez, C.E. and Motto, H.L. (2000) Suitability of Lead, Zinc and Copper Added to Mineral Soils. Environmental Pollution, 107, 153-158. http://dx.doi.org/10.1016/S0269-7491(99)00111-6 
[10] Yamane, T. (1967) Statistics: An Introductory Analysis. 2nd Edition, Harper and Row, New York.

[11] Makwe, E. and Chup, C.D. (2013) Spatial Variation in Ground Pollution by Effluents from Karu Abattoir Abuja, Nigeria. Ethiopian Journal of Environmental studies and Management, 6, 489-497.

[12] FEPA (2001) Guidelines and Standards for Environmental Pollution Control in Nigeria. National Environmental Standards-Parts 2 and 3. Government Press, Lagos, 238.

[13] Nwachukwu, E., Ihedioha, J.N., Eze, I. and Agbazue, V.E. (2014) Health Risk Assessment in Relation to Heavy Metals in Water Resources in Rural Regions of South East Nigeria. International Journal of Physical Science, 9, 109-116. http://dx.doi.org/10.5897/IJPS2014.4125

[14] Adekunle, M., Adetunji, M.T., Gbadebo, A.M. and Banjoko, B (2007) Assessment of Groundwater Quality in a Typical Rural Settlement in South West Nigeria. INT. Journal of Environmental Research and Public Health, 4, 307-318.

[15] Yahaya, M.I., Mohammed, S. and Abdullahi, B.K. (2009) Seasonal Variation of Heavy Metals Concentration in Abattoir Dumping Site in Nigeria. Journal of Applied Sciences and Environmental Management, 13, 9-13. 